\title{
Molecular analysis of the most prevalent mutations of the FANCA and FANCC genes in Brazilian patients with Fanconi anaemia
}

\author{
David Enrique Aguilar Rodriguez ${ }^{1}$, Carmen Silvia Passos Lima ${ }^{1}$, Gustavo Jacob Lourenço ${ }^{1}$, \\ Maria Estela Figueiredo ${ }^{2}$, Jorge David Aivazoglu Carneiro ${ }^{3}$, Luiz Gonzaga Tone ${ }^{4}$, \\ Juan Clinton Llerena Jr. ${ }^{5}$, Raquel Alves Toscano ${ }^{6}$, Silvia Brandalise ${ }^{7}$, Walter Pinto Júnior ${ }^{1}$, \\ Fernando Ferreira Costa $^{1}$ and Carmen Sílvia Bertuzzo ${ }^{1}$ \\ ${ }^{1}$ Universidade Estadual de Campinas, Campinas, SP, Brazil. \\ ${ }^{2}$ Universidade Federal de São Paulo, São Paulo, SP, Brazil. \\ ${ }^{3}$ Universidade de São Paulo, São Paulo, SP, Brazil. \\ ${ }^{4}$ Universidade de São Paulo, Campus de Ribeirão Preto, São Paulo, SP, Brazil. \\ ${ }^{5}$ Fundação Oswaldo Cruz, Rio de Janeiro, RJ, Brazil. \\ ${ }^{6}$ Universidade de Brasília, Brasília, DF, Brazil. \\ ${ }^{7}$ Centro Boldrini, Campinas, SP, Brazil.
}

\begin{abstract}
Fanconi anaemia (FA) is a recessive autosomal disease determined by mutations in genes of at least eleven complementation groups, with distinct distributions in different populations. As far as we know, there are no reports regarding the molecular characterisation of the disease in unselected FA patients in Brazil. Objective: This study aimed to investigate the most prevalent mutations of FANCA and FANCC genes in Brazilian patients with FA. Methods: Genomic DNA obtained from 22 racially and ethnically diverse unrelated FA patients (mean age \pm SD: $14.0 \pm 7.8$ years; 10 male, 12 female; 14 white, 8 black) was analysed by polymerase chain reaction and restriction site assays for identification of FANCA ( $\triangle 3788-3790)$ and FANCC $(\triangle 322 \mathrm{G}$, IVS4+4A $\rightarrow$ T, W22X, L496R, R548X, Q13X, R185X, and L554P) gene mutations. Results: Mutations in FANCA and FANCC genes were identified in 6 $(27.3 \%)$ and $14(63.6 \%)$ out of 22 patients, respectively. The disease could not be attributed to the tested mutations in the two remaining patients enrolled in the study (9.1\%). The registry of the two most prevalent gene abnormalities $(\Delta 3788-3790$ and IVS $4+4 \rightarrow \mathrm{T})$ revealed that they were present in $18.2 \%$ and $15.9 \%$ of the FA alleles, respectively. Additional FANCC gene mutations were found in the study, with the following prevalence: $\triangle 322 \mathrm{G}(11.4 \%)$, W22X (9.1\%), Q13X (2.3\%), L554P (2.3\%), and R548X (2.3\%) of total FA alleles. Conclusion: These results suggest that mutations of FANCA and FANCC genes are the most prevalent mutations among FA patients in Brazil.
\end{abstract}

Key words: Fanconi anaemia, DEB test, molecular diagnosis, FANCA, FANCC.

Received: April 5, 2004; Accepted: November 11, 2004.

\section{Introduction}

Fanconi anaemia (FA) is an autosomal recessive disease characterised by a very high frequency of bone marrow failure and many other manifestations, including but not restricted to severe birth defects and marked predisposition to malignancies, especially acute myeloid leukaemia and, to a lesser extent, solid tumours (Young and Alter, 1994; Alter and Young, 1998; Alter, 2003).

Send correspondence to Carmen Sílvia Bertuzzo. Universidade Estadual de Campinas, Departamento de Genética, Rua Tessália Vieira de Camargo 126, 13081-970 Barão Geraldo, Campinas, São Paulo, Brazil. E-mail: bertuzzo@fcm.unicamp.br.
FA cells exhibit spontaneous chromosomal instability and hypersensitivity to DNA cross-linking agents such as diepoxybutane (DEB) and mitomycin C (Auerbach and Wolman, 1976) and the resulting increase in chromosome breakage provides the basis for a diagnostic test (Auerbach, 1993).

Complementation analysis by cell fusion and correction of cross-linker hypersensitivity has delineated at least eleven complementation groups (A, B, C, D1, D2, E, F, G, L, I, J) (Joenje and Patel, 2001; Meetei et al., 2003) and seven genes have been cloned ( $F A N C A, C, D 2, E, F, G$ and L) (Strathdee et al., 1992; Whitney et al., 1993; Lo Tem Foe et al., 1996; De Winter et al., 1998; De Winter et al., 2000; 
Timmers et al., 2001; Meetei et al., 2003). Four FA-D1 patients were shown to possess biallelic mutations in the breast cancer susceptibility gene BRCA2 (Levitus et al., 2003). FANCA and FANCC mutations are the most prevalent, accounting for approximately $65 \%$ and $5-15 \%$ of FA patients (Tischkowitz and Hodgson, 2003).

The prevalence of distinct FA gene mutations is variable in different populations (Tischkowitz and Hodgson, 2003). FANCA mutations are more common in Afrikaners (Tipping et al., 2001) and FANC in Ashkenazi Jews and Japanese (Yamashita et al., 1996; Gillio et al., 1997; Futaki et al., 2000; Tamary et al., 2003).

The relationship between the complementation group and mutation type and the clinical outcome of the patients with disease is controversial. Patients with FANCA and $F A N C G$ mutations appear to constitute a high risk group according to some authors (Faivre et al., 2000). In contrast, The International Fanconi Anaemia Register revealed a significantly earlier onset of bone marrow failure and poorer survival rates for complementation group $\mathrm{C}$ compared with groups A and G. Moreover, there was no significant difference in the time for haematologic or nonhaematologic neoplasm development between FA groups of patients (Kutler et al., 2003).

The ethnic origin of the Brazilian population is highly heterogeneous, consisting of indigenous Amerindians and immigrants from Europe, Africa, and Asia (Alves-Silva et al., 2000; Carvalho-Silva et al., 2001).

The $\Delta 3788-3790$ and IVS8-2A $>$ G gene mutations were found in a group of Brazilian FA patients seen at a single bone marrow transplantation service, and were described as the most common FANCA and FANCG Brazilian mutations by the International Fanconi Anemia Registry (IFAR) (Levran et al., 1997; Auerbach et al., 2003). As far as we know, there are no reports regarding the molecular analysis of FA in unselected populations of our country. Therefore, this was the aim of the study presented herein.

\section{Material and Methods}

\section{Eligibility requirements}

All unrelated patients with confirmed FA, attended at the Medical Genetic and the Haematology services of UNICAMP and Haemotherapy Centres of several Brazilian Universities, were considered as fully eligible for the present study. The diagnosis of the disease was based on clinical and laboratory data, including haematological analysis, bone marrow aspiration and biopsy, and was confirmed by DEB test. The study protocol was approved by the local Research Ethics Committee.

\section{DEB test}

The DEB test was performed at the Cytogenetics Laboratory of the Haematology and Haemotherapy Centre of the State University of Campinas, according to conven- tional methods (Rosendorff and Bernstein, 1988; Auerbach et al., 1989).

\section{Molecular Analysis of FANCA and FANCC genes}

Genomic DNA was obtained from peripheral blood of patients enrolled in the study using the salt/chloroform method (Müllenbach et al., 1989). FANCA and FANCC mutations were analysed by polymerase chain reaction (PCR) followed by restriction site assays.

$F A N C A$ and $F A N C C$ exonic sequences of interest were amplified by PCR using primers described by Levran et al. (1997) and Gibson et al. (1996). PCR was carried out in $25 \mu \mathrm{L}$ reactions with $250 \mathrm{ng}$ of genomic DNA, $10 \mathrm{ng} / \mu \mathrm{L}$ of each primer, $0.5 \mathrm{mM}$ of each dNTP, and 1.5 units of Taq polymerase in a buffer containing $6.7 \mathrm{mM} \mathrm{MgCl}_{2}$. After initial denaturation at $94^{\circ} \mathrm{C}$ for $5 \mathrm{~min}$, samples were amplified for 30 denaturation cycles at $94{ }^{\circ} \mathrm{C}$ for $1 \mathrm{~min}$, annealing at $51-60{ }^{\circ} \mathrm{C}$, and extension at $72{ }^{\circ} \mathrm{C}$ for $1 \mathrm{~min}$, followed by a final 5 min extension at $72{ }^{\circ} \mathrm{C}$.

PCR products were then digested with 5-10 units of the appropriate restriction enzyme for a minimum of $2 \mathrm{~h}$ at $37{ }^{\circ} \mathrm{C}$ (50C for $\left.\mathrm{Bcl} \mathrm{I}\right)$, according to previously described techniques (Gibson et al., 1996; Levran et al., 1997) and analysed on horizontal $7 \%$ polyacrylamide gel.

The investigated gene mutations, restriction enzymes, and sizes of the normal and mutant gene fragments obtained from PCR and restriction site assays performed in the study are presented in Table 1.

\section{Results}

The clinical and laboratory features of 22 FA patients enrolled in the study are presented in Table 2 . Their mean age \pm SD was $14.0 \pm 7.8$ years (range: $2-33$ years); 10 patients were male and 12 female, 14 were white and 8 black. Sixteen patients presented congenital abnormalities such as microphthalmia ( 8 cases), microcephaly ( 4 cases), abnormalities of the thumbs (5 cases), café-au-lait spots (4 cases), hyperpigmentation (4 cases), short stature (2 cases), genital abnormalities (1 case), and renal aplasia (1 case). Short stature was the only physical abnormality identified in FANCA patients. Variable degrees of peripheral cytopenia and positive DEB test were found in all patients enrolled in the study. Cases 1, 2, 16 and 22 are children of consanguineous parents (18\%).

FA was attributed to $\Delta 3788-3790$ mutation of the FANCA gene in 6 out of $22(27.3 \%)$ patients. The gene abnormality was present in $18.2 \%$ of FA alleles. Mutations of the FANCC gene were found in 14 out of 22 (63.6\%) patients, with the following prevalence: $15.9 \%$ for IVS4+4A $\rightarrow \mathrm{T}, 11.4 \%$ for $\Delta \mathrm{G} 322,9.1 \%$ for $\mathrm{W} 22 \mathrm{X}, 2.3 \%$ for $\mathrm{Q} 13 \mathrm{X}$, $2.3 \%$ for L554P, and $2.3 \%$ for R548X on FA alleles. The analysed mutations were not found in 2 out of $22(9.1 \%)$ patients enrolled in the study. Figure 1 shows the analysis for IVS4+4A $\rightarrow$ T mutation. 
Table 1 - Fragments observed after digestion with respective restriction enzymes for the distinct analysed mutations in Fanconi anaemia patients.

\begin{tabular}{lccccc}
\hline Mutation & Gene & Restriction enzyme & Result of PCR & Normal fragments & Mutant fragments \\
\hline$\Delta 3788-3790$ & FANCA & MboII & $160 \mathrm{bp}$ & $130+30$ & 160 \\
$\mathrm{IVS4}+4 \mathrm{~A} \rightarrow \mathrm{T}$ & FANCC & Sca I & $131 \mathrm{bp}$ & $108+23$ & 131 \\
$\Delta \mathrm{G} 322$ & FANCC & Bsp1286 I & $151 \mathrm{bp}$ & $129+22$ & 152 \\
$\mathrm{~W} 22 \mathrm{X}$ & FANCC & FoK I & $221 \mathrm{bp}$ & $204+17$ & $187+17+17$ \\
$\mathrm{Q} 13 \mathrm{X}$ & FANCC & Bcl I & $250 \mathrm{bp}$ & $227+23$ & 250 \\
$\mathrm{~L} 554 \mathrm{P}$ & FANCC & Bbv I & $364 \mathrm{bp}$ & $260+104$ & 364 \\
$\mathrm{R} 548 \mathrm{X}$ & FANCC & Ava I & $364 \mathrm{bp}$ & $231+133$ & 364 \\
$\mathrm{~L} 496 \mathrm{R}$ & FANCC & Hha I & $303 \mathrm{bp}$ & 303 & $218+85$ \\
$\mathrm{R} 185 \mathrm{X}$ & FANCC & Nla III & $122 \mathrm{bp}$ & $105+17$ & $74+31+17$ \\
\hline
\end{tabular}

PCR, polymerase chain reaction; bp, base pairs.

Table 2 - Clinical and molecular features of 22 patients with Fanconi anaemia.

\begin{tabular}{|c|c|c|c|c|c|}
\hline Case & Age (years) & Gender & Race & Abnormal gene & Genotype \\
\hline 1 & 28 & Female & White & FANCA & $\Delta 3788-3790 / \Delta 3788-3790$ \\
\hline 2 & 23 & Female & Black & $F A N C A$ & $\Delta 3788-3790 / \Delta 3788-3790$ \\
\hline 3 & 8 & Male & White & $F A N C A$ & $\Delta 3788-3790 / \mathrm{NI}$ \\
\hline 4 & 6 & Male & White & FANCA & $\Delta 3788-3790 / \mathrm{NI}$ \\
\hline 5 & 15 & Female & White & $F A N C A$ & $\Delta 3788-3790 / \mathrm{NI}$ \\
\hline 6 & 10 & Female & White & $F A N C A$ & $\Delta 3788-3790 / \mathrm{NI}$ \\
\hline 7 & 18 & Male & White & FANCC & $\mathrm{IVS} 4+4 \mathrm{~A} \rightarrow \mathrm{T} / \Delta \mathrm{G} 322$ \\
\hline 8 & 10 & Female & White & FANCC & $\mathrm{IVS} 4+4 \mathrm{~A} \rightarrow \mathrm{T} / \Delta \mathrm{G} 322$ \\
\hline 9 & 12 & Male & White & FANCC & $\mathrm{IVS} 4+4 \mathrm{~A} \rightarrow \mathrm{T} / \Delta \mathrm{G} 322$ \\
\hline 10 & 8 & Male & White & $F A N C C$ & $\mathrm{IVS} 4+4 \mathrm{~A} \rightarrow \mathrm{T} / \mathrm{NI}$ \\
\hline 11 & 18 & Male & Black & FANCC & $\mathrm{IVS} 4+4 \mathrm{~A} \rightarrow \mathrm{T} / \mathrm{NI}$ \\
\hline 12 & 15 & Female & Black & FANCC & $\mathrm{IVS} 4+4 \mathrm{~A} \rightarrow \mathrm{T} / \mathrm{NI}$ \\
\hline 13 & 20 & Female & Black & $F A N C C$ & $\mathrm{IVS} 4+4 \mathrm{~A} \rightarrow \mathrm{T} / \mathrm{NI}$ \\
\hline 14 & 18 & Female & Black & FANCC & $\Delta \mathrm{G} 322$ / NI \\
\hline 15 & 14 & Male & White & FANCC & $\Delta \mathrm{G} 322$ / W22X \\
\hline 16 & 14 & Male & White & FANCC & $\mathrm{W} 22 \mathrm{X} / \mathrm{W} 22 \mathrm{X}$ \\
\hline 17 & 2 & Male & White & FANCC & W22X/NI \\
\hline 18 & 33 & Female & White & FANCC & Q13X/NI \\
\hline 19 & 19 & Female & Black & $F A N C C$ & L554P / NI \\
\hline 20 & 5 & Male & Black & $F A N C C$ & R548X/ NI \\
\hline 21 & 10 & Female & White & NI & NI / NI \\
\hline 22 & 3 & Female & Black & NI & $\mathrm{NI} / \mathrm{NI}$ \\
\hline
\end{tabular}

NI, not identified.

Two pre-symptomatic patients with FA were identified in our familial studies (Cases 1 and 2).

\section{Discussion}

We have screened the $\Delta 3788-3790$ mutation of the $F A N C A$ and eight mutations (IVS4+4 A $\rightarrow \mathrm{T}, \Delta \mathrm{G} 322$, W22X, Q13X, L554P, R548X, L496R, and R185X) of the
FANCC genes in an unselected group of Brazilian patients with confirmed FA diagnosis.

The median age of the studied group, 14 years old, was higher than those obtained in previous reports, which was 7 years old (McMullin et al., 1991; Auerbach and Allen, 1994; Butturini et al., 1994), and may be attributed to the difficulties in achieving a reference service for FA diagnosis in the country. The congenital abnormalities were 


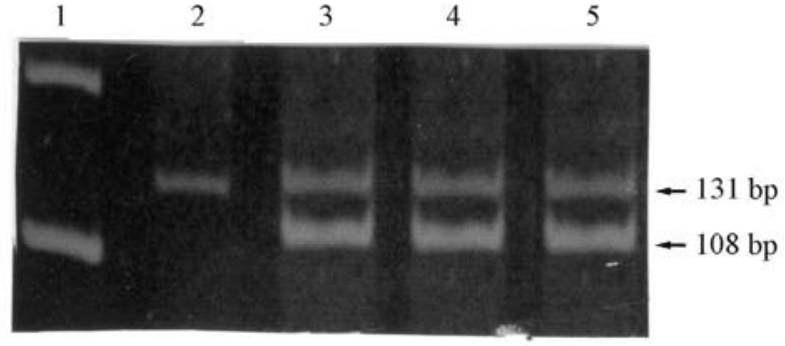

Figure 1 - Polymerase chain reaction and restriction site assays for detection of IVS4+4A $\rightarrow$ T mutation of the FANCC gene in Fanconi anaemia. Ethidium-bromide stained $7 \%$ polyacrylamide gel showing fragments of $131 \mathrm{bp}$ and $108 \mathrm{bp}$ corresponding to the mutant and normal alleles, respectively. Lane 1 shows the DNA size marker leader $100 \mathrm{bp}$. Lane 2 shows the result from an individual with homozygous IVS4+4A $\rightarrow$ T mutation used as control, and lanes 3 to 5 show the results from heterozygous individuals.

more frequent and severe in FA determined by FANCC gene mutations, particularly in cases with IVS4+4 A $\rightarrow$ T mutations, in accordance with previous reports (Faivre $e t$ al., 2000).

Interestingly, the disease was found in $8(36.4 \%)$ patients of African origin in our group, in disagreement with the reports of Rosendorff et al. (1987) and MacDougall et al. (1990), in which the disease was rare in this race.

Mutations in the FANCC and FANCA genes accounted for approximately two-thirds and one-third of our cases. The disease was not determined by the tested mutations in only $9.1 \%$ of analysed cases. Therefore, FANCC gene mutations were the most prevalent in our group of patients (14 patients), in disagreement with previous reports that show to a higher prevalence of FANCA mutations in the majority of populations (Tischkowitz and Hodgson, 2003).

Levran et al. (1997) and Auerbach et al. (2003) described the $\triangle 3788-3790$ and IVS8-2A $>\mathrm{G}$ as the most common Brazilian mutations of FANCA and FANCC genes. As far as we know, both studies included Brazilian patients from a single bone marrow transplantation service, and may have included predominantly patients with the most severe disease forms. In our sample there were both patients with slight and severe haematological manifestations. As we did not select patients for study, it is possible that mutations of the FANCC gene represent a particular characteristic of the Brazilian population.

The most prevalent mutation of FANCA gene in our group was $\triangle 3788-3790$, in accordance with the report by Levran et al. (1997). The second most common mutation was the IVS4+4 A $\rightarrow$ T of the FANCC gene (Yamashita et al., 1996; Gillio et al., 1997; Tamary et al., 2003).

In addition, the molecular analysis performed in our study was also important for early diagnosis of the disease, identification of pre-symptomatic and unaffected siblings with FA, as well as genetic counselling for the family.
Another fact that draws our attention is the high number of compound heterozygotes among FA patients. Since FA is considered a rare disease, a high rate of consanguineous parents and a larger number of homozygotes was expected, but not found in study. Our data suggest that FA may not be as rare as thought and taking into account its variable expressivity, many cases may be undiagnosed.

In conclusion, these results present preliminary evidence that FANCA and FANCC gene mutations are the most prevalent mutations among Brazilian FA patients. However, a large study concerning the molecular analysis of the Brazilian FA patients from different areas of the country should be carried out to clarify this issue.

\section{Acknowledgments}

This project was supported by Fundação de Amparo à Pesquisa do Estado de São Paulo (FAPESP).

\section{References}

Alter BP and Young NS (1998) Inherited bone marrow failure syndromes. In: Nathan DG, Ginsburg D and Orkin SH (eds) Hematology of Infancy and Childhood. Philadelphia, WB Saunders, pp 280-365.

Alter BP (2003) Cancer in Fanconi anemia. Cancer 101:425-440.

Alves-Silva J, Silva-Santos M, Guimarães PE, Ferreira AC, Bandelt HJ, Pena SD and Prado VF (2000) The ancestry of Brazilian mtDNA lineages. Am J Hum Genet 67:444-461.

Auerbach AD and Wolman SR (1976) Susceptibility of Fanconi's anaemia fibroblasts to chromosome damage by carcinogens. Nature 261:494-496.

Auerbach AD, Rogatko A and Schroeder-Kurth TM (1989) International Fanconi Anemia registry: Relation of clinical symptoms to diepoxybutane sensitivity. Blood 73:391-396.

Auerbach AD (1993) Fanconi anemia diagnosis and the diepoxybutane (DEB test). Exp Hematol 21:731-733.

Auerbach AD and Allen RG (1994) Leukemia and preleukemia in Fanconi anemia patients. A review of the literature and report of the International Fanconi Anemia Registry study. Blood 51:1-12.

Auerbach AD, Greenbaum J, Pujara K, Batish SD, Bitencourt MA, Kokemohr I, Schneider H, Lobitzc S, Pasquini R, Giampietro PF, Hanenberg H and Levran O (2003) Spectrum of sequence variation in the FANCG gene: An International Fanconi Anemia Registry (IFAR) study. Human Mutat 21:158-168.

Butturini A, Gale RP, Verlander PC, Adler-Brecher B, Gillio AP and Auerbach AD (1994) Hematologic abnormalities in Fanconi anemia: An International Fanconi Anemia Registry study. Blood 84:1650-1655.

Carvalho-Silva DR, Santos FR, Rocha J and Pena SD (2001) The phylogeography of Brazilian Y-chromosome lineages. Am J Hum Genet 68:281-6.

De Winter JP, Waisfisz Q, Rooimans MA, van Berkel CG, Bosnoyan-Collins L, Alon N, Carreau M, Bender O, Demuth I, Schindler D, Pronk JC, Arwert F, Hoehn H, Digweed M, Buchwald M and Joenje H (1998) The Fanconi anaemia group $\mathrm{G}$ gene FANCG is identical with XRCC9. Nat Genet 20:281-283. 
De Winter JP, Leveille F, Van Berkel CG, Rooimans MA, van Der Weel L, Steltenpool J, Demuth I, Morgan NV, Alon N, Bosnoyan-Collins L, Lightfoot J, Leegwater PA, Waisfisz Q, Komatsu K, Arwert F, Pronk JC, Mathew CG, Digweed M, Buchwald M and Joenje H (2000) Isolation of a cDNA representing the Fanconi anemia complementation group $\mathrm{E}$ gene. Am J Hum Genet 67:1306-1308.

De Winter JP, Rooimans MA, Van Der Weel L, van Berkel CG, Alon N, Bosnoyan-Collins L, de Groot J, Zhi Y, Waisfisz Q, Pronk JC, Arwert F, Mathew CG, Scheper RJ, Hoatlin ME, Buchwald M and Joenje H (2000) The Fanconi anaemia gene FANCF encodes a novel protein with homology to ROM. Nat Genet 24:15-16.

Faivre L, Guardiola P, Lewis C, Dokal I, Ebell W, Zatterale A, Altay C, Poole J, Stones D, Kwee ML, van Weel-Sipman M, Havenga C, Morgan N, de Winter J, Digweed M, Savoia A, Pronk J, de Ravel T, Jansen S, Joenje H, Gluckman E and Mathew CG (2000) Association of complementation group and mutation type with clinical outcome in Fanconi anemia. Blood 96:4064-4070.

Futaki M, Yamashita T, Yagasaki H, Toda T, Yabe M, Kato S, Asano S and Nakahata T (2000) The IVS4 + 4 A to T mutation of the Fanconi anemia gene FANCC is not associated with severe phenotype in Japanese patients. Blood 95:1493-1498

Gibson RA, Morgan NV, Goldstein LH, Pearson IC, Kesterton IP, Foot NJ, Jansen S, Havenga C, Pearson T, de Ravel TJ, Cohn RJ, Marques IM, Dokal I, Roberts I, Marsh J, Ball S, Milner RD, Llerena JC Jr, Samochatova E, Mohan SP, Vasudevan P, Birjandi F, Hajianpour A, Murer-Orlando M and Mathew CG (1996) Novel mutations and polymorphisms in the Fanconi anemia group $\mathrm{C}$ gene. Hum Mutat 8:140-148

Gillio AP, Verlander PC, Batish SD, Giampietro PF and Auerbach AD (1997) Phenotypic consequences of mutations in the Fanconi anemia FAC gene: an International Fanconi Anemia Registry study. Blood 90:105-110.

Joenje H and Patel KJ (2001) The emerging genetic and molecular basis of Fanconi anaemia. Nat Rev Genet 2:446-457.

Kutler DI, Singh B, Satagopan J, Batish AD, Berwich M, Giampietro PF, Hanenberg H and Auerbach AD (2003) A 20-year perspective on the International Fanconi Registry (IFAR). Blood 101: 1249-1256.

Levitus M, Rooiman MA, Steltenpool J, Cool NFC, Oostra AB, Mathew CG, Hoatlin ME, Waisfisz Q, Arwert F, de Winter JP and Joenje H (2003) Heterogeneity in Fanconi anemia: evidence for two new genetic subtypes. Blood 20 (online).

Levran O, Erlich T, Magdalena N, Gregory JJ, Batish SD, Verlander PC and Auerbach AD (1997) Sequence variation in the Fanconi anaemia gene FAA. Proc Natl Acad Sci USA 94:13051-13056.

Lo Ten Foe JR, Rooimans MA, Bosnoyan-Collins L, Alon N, Wijker M, Parker L, Lightfoot J, Carreau M, Callen DF, Savoia A, Cheng NC, van Berkel CG, Strunk MH, Gille JJ, Pals G, Kruyt FA, Pronk JC, Arwert F, Buchwald M and
Joenje H (1996) Expression cloning of a cDNA for the major Fanconi anemia gene, FAA. Nat Genet 14:320-323.

Macdougall G, Greff MC, Rosendorff J and Bernstein R (1990) Fanconi anemia in black African children. Am J Med Genet 36:408-413.

Mcmullin F, Mahendra P, Hain R and Barrett AJ (1991) Myelodysplasia as the initial presentation of Fanconi's anemia in a phenotypically normal child. Clin Lab Haematol 13:387389.

Meetei AR, De Winter JP, Medhurst AL, Wallish Q, Waisfisz Q, van de Vrugt HJ, Oostra AB, Yan Z, Ling C, Bishop CE, Hoatlin ME, Joenje H and Wang W (2003) A novel ubiquitin ligase is deficient in Fanconi anemia. Nature Genet. 35:165-170.

Müllenbach R, Lagoda PJL and Welter C (1989) An efficient salt-chloroform extraction of DNA from blood and tissues. Trend Genet 5:391.

Rosendorff J, Bernstein R, Macdougall L and Jenkins T (1987) Fanconi anemia: another disease of unusually high prevalence in the Africaans population of South Africa. Am J Med Genet 36:27:793-797.

Rosendorff J and Bernstein R (1988) Fanconi's anemiachromosome breakage studies in homozygotes and heterozygotes. Cancer Genet Cytogenet 33:175-183.

Strathdee CA, Duncan AM and Buchwald M (1992) Evidence for at least four Fanconi anemia genes including FACC on chromosome 9. Nat Genetic 1:196-198.

Tamary H, Bar-Yam R, Zemach M, Dgany O, Shalmon L and Yaniv I (2003) The molecular biology of Fanconi anemia. Isr Med Assoc J 4:819-823.

Timmers C, Taniguchi T, Hejna J, Reifsteck C, Lucas L, Bruun D, Thayer M, Cox B, Olson S, D'Andrea AD, Moses R and Grompe M (2001) Positional cloning of a novel Fanconi anemia gene, FANCD2. Mol Cell 7:241-248.

Tipping AJ, Pearson T, Morgan NV, Gibson RA, Kuyt LP, Havenga $C$, Gluckman $E$, Joenje $H$, de Ravel $T$, Jansen $S$ and Mathew CG (2001) Molecular and genealogical evidence for a founder effect in Fanconi anemia families of the Afrikaner population of South Africa. Proc Natl Acad Sci USA 98:5734-5739.

Tischkowitz MD and Hodgson SV (2003) Fanconi anaemia. J Med Genet 40:1-10.

Whitney MA, Saito H, Jakobs PM, Gibson RA, Moses RE and Grompe M (1993) A common mutation in the FACC gene causes Fanconi anaemia in Ashkenazi Jews. Nat Genet 4:202-205.

Yamashita T, Wu N, Kupfer G, Corless C, Joenje H, Grompe M and D'Andrea AD (1996) Clinical variability of Fanconi anemia (type $\mathrm{C}$ ) results from expression of an amino terminal truncated Fanconi anemia complementation group C polypeptide with partial activity. Blood 87:4424-4432.

Young NS and Alter BP (1994). Aplastic anemia: Acquired and inherited. Philadelphia, WB Saunders, 410 pp.

Associate Editor: Mayana Zatz 